Vol. 5 (1996): 219-220.

\title{
Horticultural economics research needs more resources
}

Finnish horticulture faced major changes in 1995 due to Finland's joining the European Union (EU) on January 1, 1995. The change in market conditions was rapid. The withdrawal of the border protection meant that foreign products came for sale permanently throughout the year. Consequently, the prices went down. Compared with the 1992-1993 average, the producer prices of vegetables in greenhouses fell by $35 \%$ and the prices of flowers and plants by $21 \%$. The producer prices of open-field vegetables fell by $25 \%$, the prices of apples by $30 \%$ and the prices of berries by $15 \%$. However, the variation in the price development within groups was substantial.

Although the producer prices fell sharply in 1995 , there was only a slight fall in the production costs. The horticultural cultivation is very intensive with respect to the use of land and labour. Labour plays a central role in the costs. The slight fall in the input prices, that was recorded in 1995, was fully offset by the $8 \%$ increase in the labour costs from 1993 to 1995. The fall in the producer prices and the unchanged production costs weakened the financial situation of the Finnish horticultural producers.

In order to support the adjustment to the EU membership, the Finnish horticultural producers are paid a national support during the trans- itional period, 1995-1999. The support, that is reduced gradually, will partly compensate the income losses caused by the fallen producer prices. A long-term support was accepted by the EU for the Northern Finland.

As a consequence of the increased support, the EU membership increased the public control in the Finnish horticulture. The lack of data is obvious, when it comes to data about the economic situation of the horticultural enterprises. This is the case especially for the open-field production. There are a number of reasons for the situation: the horticultural enterprises have traditionally dealt with production and marketing on their own. Matters concerning economy have been classified by the farmers as private. Furthermore, the lack of support systems before joining the EU has decreased the need for nation-wide economic monitoring in horticulture.

The lack of data has many shapes. In the official statistics, horticultural enterprises are grouped in no more than one or two categories despite the fact that the enterprises differ considerably from each other. This makes the interpretation of the statistics difficult, and it also makes the data about horticultural enterprises less useful. The horticultural economics suffers from the fact that the education and the research are underdeveloped. Moreover, the advisory 


\section{AGRICULTURAL AND FOOD SCIENCE IN FINLAND}

Laurila, I.P.: Horticultural economics research needs more resources (News and Reports)

service in horticultural economics, especially concerning the production in open field, is insufficient.

The increased competition and the pressures on profitability within the markets of horticultural products emphasises the need for economic research in horticulture. Simultaneously, the need for advisory services and data availability is increasing. The implementation of a horticultural policy requires data about the economic situation of the horticultural enterprises and the factors that affect their profitability. Fortunately, there has been some progress in this field. In 1996, the horticultural farm accountancy system will be put into practice. The system will at last make it possible to collect information about the incomes of the growers.

In addition to the farm accountancy system, the public control requires up-date information on the prices of horticultural products. This information is available through Kasvistieto, an organisation owned by the producers. The information is forwarded to the Ministry of Agriculture and Forestry and the European Commission, that uses it as a base for decisions concerning the entry price system.

This article is based on the seminar "Current topics in horticultural economics" organised by the Scientific Agricultural Society of Finland and held at the University of Helsinki, on February 15,1996 . The seminar was chaired by Taina Vesanto from the Ministry of Agriculture and Forestry. The speakers were Seppo Aaltonen from the Pellervo Economic Research Institute, Sirpa Lehtimäki and Katarina Lassheikki from the Central Organisation for Finnish Horticulture and Petri Knaapinen from the Agricultural Economics Research Institute.

Ilkka P. Laurila Agricultural Economics Research Institute, P.O. Box 3, FIN-00411 Helsinki, Finland

\section{SELOSTUS}

\section{Puutarhaekonominen tutkimus tarvitsee lisää resursseja}

EU-jäsenyys heikensi Suomen puutarhatalouden kannattavuutta. Jäsenyyden myötä puutarhatuotantoa suojanneet tuontirajoitteet poistettiin, minkä seurauksena hintataso laski. Vuosiin 1992 ja 1993 nähden vihannesten ja omenan tuottajahinnat vuonna 1995 olivat 25-35\% alhaisemmat. Kukkien, taimien ja marjojen hinnat laskivat hieman vähemmän. Tuotantokustannukset eivät vastaavasti laskeneet, sillä työkustannusten nousu kompensoi ostopanosten lievää laskua. Tulonmenetystä vaimennetaan siirtymäkauden tuella, jota maksetaan kansallisista varoista vuoteen 1999 saakka ja pohjoista tukea vielä sen jälkeenkin.

EU-jäsenyyden myötä puutarhatalous kytkettiin aiempaa tiiviimmin osaksi maatalouden sektorihallintoa. Samalla kävi ilmeiseksi, että puutarhatalouden kannattavuusseurannan tilastoinnissa on puutteita.
Tilastojen käyttökelpoisuutta heikentää mm. se, että puutarhatalouden yritysrakenne on hyvin monimuotoinen, mutta virallisissa tilastoissa puutarhayritykset käsitellään vain yhtenä tai kahtena ryhmänä. Tältä osin tilanne paranee vuoden 1996 aikana, kun Suomessa aloitetaan puutarhatalouden kannattavuuskirjanpito. Puutarhatalous kärsii myös puutarhaekonomian heikosta resursoinnista oppiaineena ja alan tutkimuksen vähäisyydestå.

Kirjoitus perustuu Suomen Maataloustieteellisen Seuran järjestämään "Puutarhaekonomian ajankohtaisia kysymyksiä” -seminaariin, joka pidettiin 15. helmikuuta 1996 Helsingin yliopiston tiloissa Viikissä.

Ilkka P. Laurila

Maatalouden taloudellinen tutkimuslaitos 